\title{
Impersonating Islanders: \\ Inauthenticity, Sexuality, and the Making of the Tahitian Speaker in 1770s British Poetry
}

\author{
James Mulholland \\ North Carolina State University
}

The first Polynesian to set foot in Britain was a man we now know as Mai. He arrived in 1774 aboard the H. M. S. Adventure, one of the ships from James Cook's second Pacific expedition, and stayed for two years, during which time he toured London's drawing rooms, was presented at court, dined with Samuel Johnson, and was painted by Joshua Reynolds. ${ }^{1}$ His presence-and Oceanic exploration generally-inspired frenzied publication, as authors and printers capitalized on a "craze" for the Pacific. ${ }^{2}$ In this article I examine a segment of that publishing craze by focusing on two related clusters of approximately a dozen poems from the 1770s that impersonate Tahitians. The first cluster consists of satires in Mai's voice composed by British authors while he resided in England. The second set was written from the perspective of Purea, a Tahitian noblewoman and contemporary of Mai, addressed to British explorers who had visited Tahiti and had supposedly become her lovers. Nearly all of them were published anonymously. They were humorous and comedic; they trafficked in gossip and innuendo about public figures such as the amateur botanist Joseph Banks, who traveled in Cook's first Pacific expedition.

Scholars, many of whom I engage with here, have typically seen these poems as mediocre satires of aristocratic excess and libertinism or as vulgarizations of the otherwise more sophisticated debate about Enlightenment, primitivism, sexuality, and exploration. While such critics have usefully integrated these poems into the vast scholarship about eighteenth-century European encounters with the Pacific, they have also overlooked the significance of impersonation and virtualization for these poems. This oversight has meant sacrificing an important archive for understanding the consequences of print's ability to imitate voices and construct virtual beings. Such an ability is particularly salient for understanding these impersonations because, as Srinivas Aravamudan ar- 
gues, print's projections of speech and bodies allows scholars to link colonialist representations with their postcolonial revisions and uncover retrospectively the machinery of agency. ${ }^{3}$ Aravamudan defines this as "virtualization," which apprehends the process of "becoming-other" so central to the recuperation of "retroactive identification and projections of counter-hegemonic tradition." From this vantage, recognizing the importance of virtuality in these impersonations compels new attention to the complex ways that personhood, subjectformation, and sexual agency were implicated in early responses to Pacific exploration. In returning to these poems, I seek to reignite the debate about authenticity and cultural appropriation by considering instances in which exoticism and ventriloquism lead not to the representation of Tahitians as sexual objects, imperial curiosities, or ethnographic specimens, but as subjects. ${ }^{5}$

During the eighteenth century, Pamela Cheek notes, sex was refashioned into a "mode of global consciousness" that ascertained racial and national identities. ${ }^{6}$ European authors in this period began to understand the "sexual self as a virtual traveler" who emerges in concert with fantasies about foreigners' sexual lives. ${ }^{7}$ Travel, especially to the Pacific, tested conceptions of the coherent self, figured as a struggle for self-preservation, often against the voluptuous temptations of islands like Tahiti. ${ }^{8}$ These virtual and literal travels, together with experiments in selfhood, intensified the ongoing shift toward privacy and personal autonomy in British erotic life that reorganized sexual practices and regulated intimacies. ${ }^{9}$ Rapidly changing demographics transformed sexuality as people married earlier and fewer individuals remained unmarried; heterosexual practices were reoriented toward penetration, procreation, and the economy; modern sexual differentiation founded the gender system, a revolution that codified previously inchoate practices as homosexuality. ${ }^{10}$ Ultimately, the diversification of erotic lives pushed sex acts and dispositions into sociopolitical debates within an increasingly public sexual culture. ${ }^{11}$ Travel, the interiorized self, and this public sexual culture formed individuals who, Tim Hitchcock claims, "were able to use their imaginations to liberate sexual desire from its immediate social context."12

Liberating sexual desire from its immediate social context was one goal of these Tahitian poems, which brought readers into contact with exotic beings and unfamiliar sexualities as a form of virtual travel. The sexualized discourse of Pacific exploration, Lee Wallace explains, traces the "the counterimplication and historical transformation of both European and Polynesian regimes of sexuality." 13 Wallace describes this transformation as an entanglement, recalling Nicholas Thomas's influential description of the encounter between Europeans and Islanders as a series of uneven exchanges, in which Islanders were not merely subjugated by European colonialism but engaged in acts of "cultural versatility." Simultaneously, Europeans recontextualized indigenous Pacific knowledge within their own systems of knowledge and maintained vestigial connections with its Oceanic origins. ${ }^{14}$ 
By directing new attention to issues of subject-formation and sexual agency in these poems, I am not suggesting that authentic Tahitian voices were recovered by these texts. Nor am I asserting that these poems extinguish Tahitian attempts at self-representation or that they function like more ethnographically or anthropologically oriented explorer accounts of Tahitian sex. The gossip and innuendo central to these poems drew upon these accounts, most prominently John Hawkesworth's An Account of the Voyages . . (1773), which was meant to publicize the accomplishments of the British state but instead achieved notoriety for its controversial descriptions of communal Tahitian sexuality (that some commenters felt were more appropriate to lurid "foreign 'French Novels'"). ${ }^{15}$ Impersonated Tahitians appeared in other literatures, such as the popular theatrical pantomime Omai, or, A Trip Around the World (1785) and in French Enlightenment texts, most famously Denis Diderot's Supplément au Voyage de Bougainville $(1772,1792){ }^{16}$

As with these dramatic performances and travel accounts, the poems I examine here make fictional subjects seem immediately available to the reader through print. However, even as the authors of these poems were wary of this tactic, they comprehended the capacity of simulated Polynesians to create speaking positions that satirized enthusiastic (or overly pessimistic) accounts of the entangled sexualities emerging from the earliest Polynesian encounters. In fact, I analyze these impersonations because they do not seek to understand the Pacific through those proto-scientific and first-person travel accounts that have attracted so much scholarly attention. ${ }^{17}$ These impersonations were not predicated on eyewitness verifiability or cultural authenticity, but rather on the repurposing of Mai and Purea as a series of inauthentic literary companions, who exist alongside the historical figures who inspire them. I concentrate on how these poems registered those changes in European regimes of sexuality by formalizing erotic attachments between virtual Tahitians fashioned from ventriloquism and those British readers who were imagined as engrossed by them.

Impersonation, therefore, is an essential technique for appreciating these attachments because it establishes a dynamic with readers that mimicked the intimate liaisons detailed in the poems themselves. Printing what are ostensibly the enunciations of actual historical beings opens up possibilities for reading exotic voices as evidence of subjectivity. These poems imply that readers can access the feelings and sensibilities of their speakers (even as readers understand that they are fictitious). ${ }^{18}$ They offer the enticement of being addressed by alterities who confess their passionate exploits, which allows for a range of erotic responses. Sometimes impersonation proposes the inhabitation of foreign subjects as a constitutive part of reading, involving readers imaginatively in their sexual excitement. At other times these addresses, much like pornography, invite readers to act as observers, witnessing private relationships that otherwise circulated as rumor and scandal. In all of these modes, reading about others' sexual excitation suggests susceptibility to feeling similar urges one- 
self. ${ }^{19}$ Combining vicarious subjectivities with the protocols of erotic reading created powerful moments of reciprocity that span-if only momentarily-the racial and cultural gulf that divided Europeans and Tahitians. To create these momentary reciprocities between readers and textual subjects was also to engage with the politics of Pacific exploration via comparative sexuality. ${ }^{20}$

In this sense, Tahitian impersonations are humorous, ironic verse with a serious purpose; middling poetry that nonetheless illuminates some of the thorniest debates about subject-formation; ephemeral and often conventional texts, localized in place and time, that capture the broad historical impact of Tahitian sexual practices on British understandings of their own. They are examples of the "normal literature" of exploration and empire, not radically altering its paradigms, but instead puzzling out and consolidating its features. ${ }^{21}$ Considering these poems' complicated representation of cross-racial sexuality, the overlooked sophistication of their virtualizations, and their unapologetic indulgence in the art of inauthenticity, now seems like an ideal moment to reexamine them.

\section{MAKING MAI SPEAK AND THE CREATION OF THE TEMPORARY SUBJECT}

Years before Mai arrived in Britain, another Tahitian named Ahutoru traveled to France with the explorer Louis-Antoine de Bougainville. Ahutoru was of high rank and his aristocratic sense of hierarchy persisted while in Europe, which he turned to his advantage. (Bougainville noted that Ahutoru was as "supple as he was proud." $)^{22}$ Mai was required to follow a different strategy because he was from a lower rank and was viewed suspiciously by figures like Cook, who described him as a "dark ugly and downright blackguard" and who questioned whether he was the appropriate representative of Tahitian life, "not having any advantage of birth, or acquired rank; not being eminent in shape, figure or complexion." ${ }^{23}$

While Bougainville and Cook may have noted nuances in Tahitians' rank and "shape," most Europeans ignored such attributes to gossip avidly about their sexuality. After being introduced to France's elite society, Ahutoru became a marvel because he seemed to confirm Tahitian uninhibitedness. ${ }^{24}$ The French aristocrat Louis du Bachaumont reported that Ahutoru's "great passion is for women and he shows no discernment in his choice." ${ }^{\prime 25}$ And though Cook thought Mai ordinary and unattractive, he was not presented that way. One account pronounces him "lusty," "strong," and tan, while another claimed that he was a "tall, genteel, and well-made man." ${ }^{26}$ Mai's success in Britain was facilitated by wealthy patrons and by the fascination with exotic locales that, as Roy Porter has argued, presented opportunities for conceiving of "sex that was neither penalized, nor pathologized, nor exclusively procreative." ${ }^{27}$ Tahiti was alternately Edenic and corrupted, and Mai depended on such exoticism, 
flattering women (Frances Burney among them) and steering his way through British society by shifting expertly between strange and familiar modes. ${ }^{28}$ Dining with the Duke of Gloucester, for example, Mai wore traditional bark-cloth robes meant to signify an elevated social rank (that he did not possess) but also to show his appreciation for his host with his unusual dress. ${ }^{29}$ Yet Joseph Banks also had visiting cards made for Mai in London, assimilating him into accepted aristocratic norms. ${ }^{30}$

Physical characteristics were especially potent signifiers of this conflicted dynamic between enticing foreignness and familiar gentility. His tattoos, included in Reynolds's famous painting as small lines of ink on his left hand (see Fig. 1), provoked tantalizing speculation about what else might be "hidden by his clothes." ${ }^{\prime 31}$ After swimming with an undressed Mai in the countryside, George Colman, the son of one of Mai's patrons, found out what was hidden, remarking that Mai was "a specimen of pale moving mahogany, highly varnished ... [and] curiously veneered" by the tattooing across his body. ${ }^{32}$

While the body during the eighteenth century was an "inescapable textual surface," Paul Goring notes, it also possessed a "particularly acute capacity for representation because it is perpetually available in social relations." 33 These social relations are hinted at in Reynolds's painting, in which the tattoos accentuate Mai's rich dress and the exciting body underneath. Harriet Guest suggests that Mai's tattoos inscribe him with an "actual illegibility" that stigmatizes him as an "authentic object of curiosity." ${ }^{34}$ I argue that literary impersonations of Mai transform this "authentic object of curiosity" into an inauthentic, temporary subject, fashioned in such a way as to engage types of sympathetic recognition typically reserved for other portrayals of Pacific Islanders. ${ }^{35}$ To extend this difference between inscribed object and textual subject even further, I would argue that to speak for Mai, rather than to sketch or to paint him, is to assign psychic depth to what is otherwise portrayed as an illegible body. Converting Mai's varnishes and veneers into an expressive speaker provokes the possibility for reciprocity; to make Mai speak is to incite the probability of sympathetic recognition. Such recognition is asymmetrical and dependent upon the whims of the English reader. The historical being we know as Mai could not demand recognition of his personhood in the same way these literary impersonations do. Therefore, I am not suggesting that ventriloquizing Mai's voice is equivalent to creating a political actor or citizen. Nonetheless, the temporary transformation of Mai within the space of the poem into a speaker recasts him as a subject who is brought into being by the desire of English readers for exchange with the exotic, rather than merely the appreciation of a curious surface of an object.

The complex mechanics of making Mai into a temporary subject are exemplified by the anonymous "Omiah's Farewell; Inscribed to the Ladies of London" (1776), a poem which claims to be a lamentation of Mai before leaving Britain to return to Tahiti. E. H. McCormick argues that the Mai imper- 


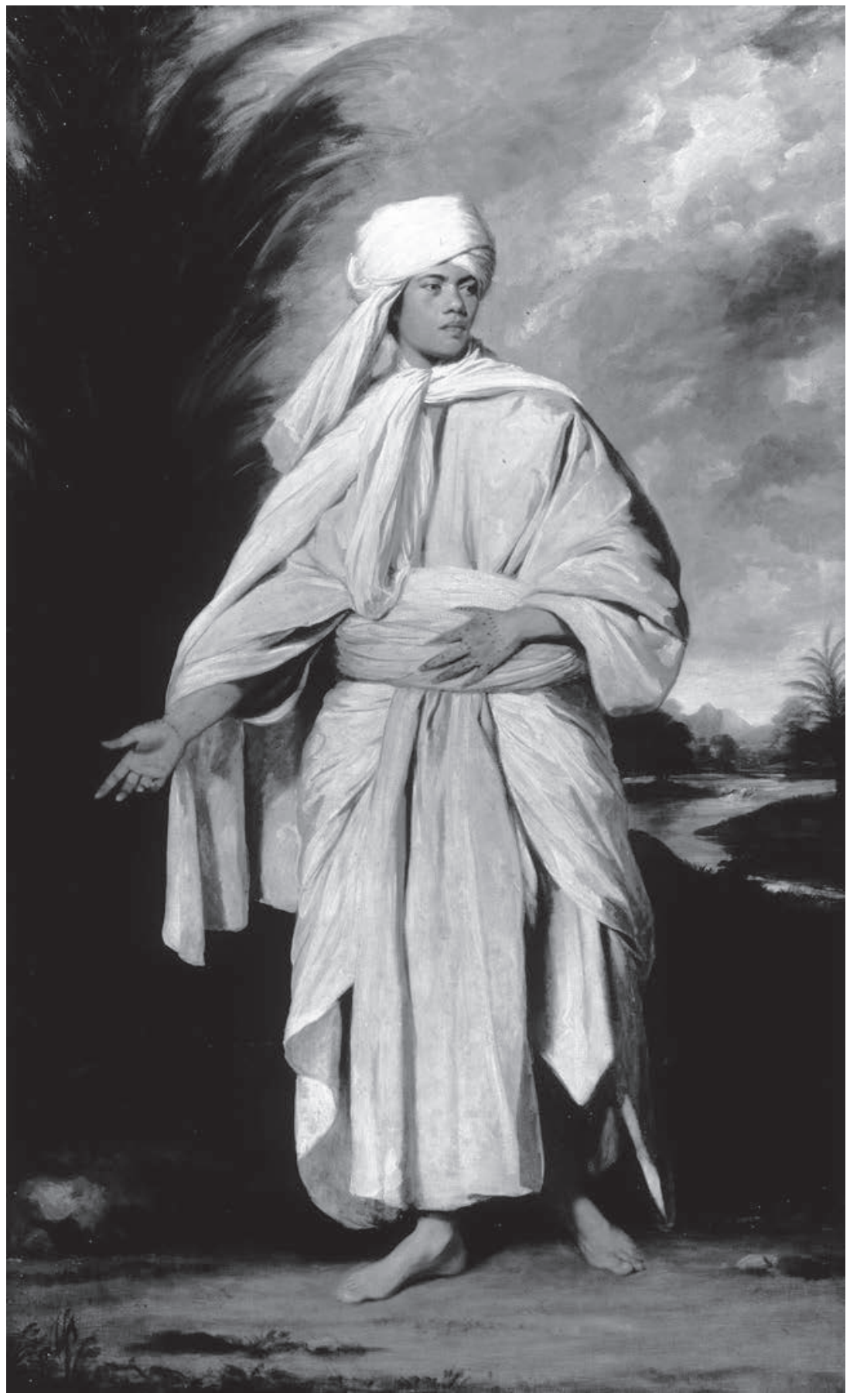

Fig. 1: Joshua Reynolds, Omai (1776). Image courtesy of Sotheby's. 
sonations satirize aristocratic excess, Pacific exploration, and adulation of the noble savage. However, McCormick's analysis understates the significance of impersonation, which elaborates an expressive subject who coexists alongside what McCormick sees as the vacantly sexual and satirical one. ${ }^{36}$ In the poem Omiah longs for British women, whose "white teeth, and bright blue eyes, and aubourn hair, / And skin, as whitest ermine soft and fair" surpasses that of Tahiti's "swarthy maids" with their "brown cheek[s]" and "tann'd neck[s]." 37 He aspires to their whiteness, even wishing to use cosmetics to lighten his disabling dark skin:

Oft' have I gaz'd, and wish'd with ardour too,

To paint my skin, and only look like you:

Oft' have I tried, but ev'ry art was vain,

No colours hid my dark Numidian stain. ${ }^{38}$

The "Numidian stain" denotes skin color that groups Omiah with non-whites. ${ }^{39}$ He seeks to use makeup—which he calls the "art of painting white and red" — to integrate into Britain. The significance of his wish to "only look like you," however, is ambiguous. ${ }^{40} \mathrm{He}$ may yearn for whiteness as a way to seem more attractive. Or his interest in "paint[ing] my skin" might indicate self-consciousness about the power of complexion to categorize: an instance of artificial color compensating for the skin color underneath it. Using cosmetics also recalls the fetish of white skin and rosy cheeks that Roxann Wheeler has defined as the "glass ceiling of color aesthetics in Britain."41

Omiah's sexuality is disciplined in this poem through the blunt racialization for which skin color is an "indelible difference" unable to be overcome without aid of adornment. ${ }^{42}$ Still, it remains unclear whether Omiah seeks to be like British women, or wants to have sex with them, or both. ${ }^{43}$ His urge to "only look like you" becomes even more fraught when he offers to carry cosmetics across the Pacific so that Tahitian women can experiment with them as English women do. Then, Omiah suggests, he would "find a welcome with my Queen again: / On her brown cheek the blushing Rose should blow, / And her tann'd neck appear more white than snow." ${ }^{44}$ Unable to be with white women in Britain, Omiah offers to produce their imitation overseas as a way of retaining the subject-making effects of appreciating their beauty. These passages that direct attention to sexuality's decipherable adorned surfaces are paired with a discussion of sensibility's capacity to hint at subjective interiors.

When ultimately forced to abandon British women at the end of the poem, Omiah offers them "all that sensibility can give." He asks that "VENUSinspire my soul!" and begs British women-and the reader-to "hear a poor untutor'd Indian's vow." 45 These proclamations of highly developed sensibilities, inspired souls, and passionate feelings are no doubt meant to satirize white male aristocratic immorality. One of the most familiar tropes found in 
eighteenth-century depictions of Mai, Guest reminds us, was the contrast between Mai's civility and its evident lack among British aristocrats. ${ }^{46}$ Yet joining pleas and vows with an account of his limiting yet alluring physique creates the possibility of sympathizing with his affective depths. The normativity of aligning sensibility and masculinity with Englishness here is powerfully disrupted by Omiah's ambiguous appetite for, and identity with, English women. The poem thus converts effeminacy into sensibility and exoticism into passionmaking external characteristics that impede his ability to partner with English women into internal expressions that distinguish him from the savage Islander. While the conflation of being a woman and having numerous women is part in the long history of effeminacy, as David Halperin points out, here the effeminate foreigner becomes a more accomplished appreciator than those white men who might be seen as naturally allied with them. ${ }^{47}$

Investing Omiah with desire for and appreciation of white women is not merely an instance of relativizing sensibility or manners. It is not merely to use sentimentality as an instrument of colonialism, as Peter Hulme suggests. ${ }^{48}$ What appears to be yet another conflation of the exotic and the hypersexual with a celebration of superior white Englishness in context turns into something more complicated: a subject, "Omiah," but one limited to those moments when he acknowledges English beauty and its superior attractions. The temporary nature of this subjectivity is highly localized to Britain, to the white women he appreciates, and to those English readers who appreciate as he does. Still, the quiet disturbance of this impersonated subject is expertly distilled by the poem itself, when Omiah exclaims that he is "the slave of Love-no other God I own, / No other God is to Omiah known." ${ }^{49}$ Enthralled by his love of English women, he is also personated by it. Omiah and the readers imagined by the poem share an attraction to the foreign, rather than a xenophobic repulsion toward difference. ${ }^{50}$ What constitutes the poem's speaking subject is therefore that same impulse that draws in its readers, who are asked to use vicariousness as an opportunity for creating fond and sentimental attachments that exist adjacent to the poem's more obviously satirical effects.

Another verse epistle, "An Historic Epistle, from Omiah, to the Queen of Otaheite" (1775), transforms Mai into a temporary subject to critique British commerce with the Pacific. Bernard Smith describes this as the "most virulent of all the poems" that ventriloquized Mai, and it ranges widely to criticize aristocracy, modern philosophy, theater, and poetry. ${ }^{51}$ It is Britain's overseas adventures, however, that receive the most condemnation, as Omiah suggests that Britain's insatiable appetite for "new luxuries" degrades the nation. ${ }^{52}$ The British, he argues, are

Urg'd by no inj'ry, prompted by no ill,

In forms they butcher, and by systems kill;

Cross o'er the seas, to ravage distant realms,

And ruin thousands worthier than themselves. ${ }^{53}$ 
The drive to discover new commercial markets causes the British to ignore other pleasures, such as sexuality, prompting Omiah to ask rhetorically, "why seek they pleasures but in mines of gold?" These pleasures differ from the peaceful desires of Tahitians, who with "love's more grateful joys enthral, / Profess one art-to live without them all." 54

Commercial corruptions particularly infect British women, who are "beauteous in vain, to no one purpose fair" and "curst with refinement, crampt by senseless rules." ${ }^{55}$ Tahitians, by contrast, champion women's sexuality as expressions of their "praise":

The arts of pleasing is a woman's praise.

The wanton kiss, the warm lascivious move,

Are female virtues Otaheiteans [Tahitians] love. ${ }^{56}$

While the Tahitians celebrate the "wanton kiss" and the "warm lascivious move," virtue in Britain is built upon "an empty name" forming a "bubble buoyant on the breath of fame." ${ }^{57}$ Uninhibited sexuality, Omiah argues, delivers more honest morals than does aristocratic hierarchy and social fame.

Of course, Tahiti possessed social differentiations as complex as those of Europe, which this poem conveniently simplifies. Nevertheless, by portraying Tahiti as a state of nature-and in particular a state that champions the social value of sexual excitation among women- "An Historic Epistle" turns Tahitian indulgence into an alternative form of morality and virtue that competes with British standards. Tahitian virtues, moreover, are meant to reform the misguided focus on money, refinement, and those "senseless rules" imposed on British women. To portray Tahiti as a natural paradise with uninhibited sexualities was one mechanism by which it altered European "regimes of sexuality." I would add that redefining sexuality as redemptive and commerce as disruptive also requires that Omiah be recast as a speaker of sensibility. At the poem's end, Omiah begs his queen that he return to Tahiti, where he can feel "candid friendship," possess a "guileless heart," and "taste unrestain'd what freedom really means." 58 The genuineness of Tahitian feeling invests them as subjects but, unlike in "Omiah's Farewell," distinguishes them from British sentiments so profoundly that the poem concludes: "what Britons talk of, Otaheiteans feel." ${ }^{\prime 59}$ Sensibility not only certifies the expressive literary speaker but also endows that speaker with the capability of condemning the British social and economic order that disrupts feeling and replaces it with the profit motive.

All of the poetic impersonations of Mai share similar tactics as the two poems that I have analyzed above: they transform an ostensibly objectified, oversexualized Oceanic traveler into an articulate feeling subject who comments on British social and sexual norms. As scholars, we tend to be suspicious of ventriloquized non-British speakers conscripted to critique British social 
norms, even as we recognize the trope's potency. And while this suspicion is warranted, these impersonations of Mai demonstrate the degree to which making foreign figures speak is a crucial means of conferring subjectivity whose effects, while momentary and partial, nonetheless exceed merely portraying them as exotic, sexualized objects.

\section{OBEREA AND THE ATTACHMENTS OF EROTIC READING}

The consequences of subject-making that I described in the previous section were repeated and intensified when British authors impersonated Purea, a noblewoman widely known in the eighteenth century as Oberea. ${ }^{60}$ As with Mai, Oberea was a source of sexual fascination; Hawkesworth's brief account of her participation in public sex and erotic dancing transformed her into a notoriously sensual figure, a woman characteristic of Tahiti and the entire "concupiscent South Seas itself." ${ }^{11}$ Through Purea, Tahitian women achieved a reputation for indulgence. This perception was based on misunderstandings of their sexuality as mindlessly libertine or as a type of prostitution-an "infamous commerce" - that distorted the otherwise civilizing effects of cross-oceanic commerce.$^{62}$ In fact, as historians and anthropologists have noted, Tahitian sex acts were often ordered and ritualistic; Tahitian women were used to establish cross-generational alliances of mutual indebtedness and to reconcile competing family groups, not unlike in Europe. ${ }^{63}$ British explorers misunderstood these Tahitian customs and social stratifications and confused specific practices-for example, those among the Tahitian sect the ariori-with those of all Tahitians. ${ }^{64}$ Authors like Hawkesworth further misconstrued these dynamics by naturalizing and universalizing what were in fact quite particular cultural and political routines.

For literary impersonators, however, this misunderstood sexuality supplied opportunities to recruit Tahitian voices for alternate social and political affiliations. The erotic Tahitian body was remade into a mode of readerly attachment to the ventriloquized Tahitian speaker that was predicated on the impulses of pornography. John Courtenay's "An Epistle (Moral and Philosophical) from an Officer at Otaheite to Lady Gr*s**n*r [Grosvenor]" (1774), for example, portrays Purea as a matriarchal monarch whose power results from her sexual license. While the majority of the poem appears from the perspective of a British sailor, one crucial instance ventriloquizes Tahitian women to describe a public encounter between a Tahitian man and young girl..$^{65}$ This episode is drawn directly from Hawkesworth's Account, but it turns his more distanced description into a vocal and dramatic reenactment. Oberea's maid, Otheothea, instructs the young girl during the sex act with an older man, telling her:

"Now gently heave, in wanton folds entwine,

"To aid his bliss, let every nerve combine; 
"See his lips tremble and his eyeballs roll,

"Suck in the last breath, and catch his flying soul."

She hears; obeys, in speechless transports drown'd,

Whilst sympathetic murmurs float around. ${ }^{66}$

Adopting Otheothea's voice shifts the poem's perspective, momentarily transporting readers into the scene of action amongst participating Tahitians and introducing a correlative for reading in the form of an admiring crowd who sympathetically murmur as they witness the sex act. Immediately after this scene concludes, the poem returns to the English sailor's vantage, who lauds the sexual encounter as the "blest employment of a Sovereign's time, / How seldom seen in Europe's barbarous clime!"67

These rapid shifts in perspective permit the poem to offer a salacious account of Tahitian sexual practices while qualifying them later with an observing English speaker. Such shifts in speaker and perspective make it difficult to evaluate the poem's political attitudes. The sailor's claim that public sexuality is a "blest employment" unknown in Europe's "barbarous climes" seems facetious, and yet such a claim reverses the typical associations of East and West, cultured and uncivilized. Interrupting the poem with the first-person address of a Tahitian woman's voice briefly involves readers in Tahitian sexual and cultural life. And while Courtenay lampoons those who would perceive innocence and virtue in Tahiti's uninhibitedness, he also connects it to differences between the Pacific and India so as to substantiate his sense that Europeans were not justified in their exploitations. ${ }^{68}$ For example, the poem's sailor wonders, "Shall Europe's spoilers call this isle their own?" before insisting that in Tahiti

No eastern plund'rers spread Oppressions gloom,

Nor check the labours of the cheerful loom;

From Leadenhall, waft famine, blood and strife,

And rob the produce of the "tree of life." 69

"Leadenhall" refers to Leadenhall Street, the London location of the British East India Company, which at the time of this poem's publication was the topic of divisive debate about regulating its conduct. ${ }^{70}$ Courtenay's epistle undercuts the notion that Tahiti is a model sexual system, but he also sees it as unspoiled, as India once was before the arrival of "plund'rers." By setting his descriptions of sexual encounters in the Pacific alongside those of India, he advances a transoceanic political consciousness that presents India as a cautionary example of what could happen to Polynesia. The targets of the poem's satire include both admirers of Pacific sexuality (as a state of nature and an expression of its noble savages) but also enthusiasts for European colonial trade that might alter that sexuality.

Of course, as with impersonations of Mai, attraction need not lead to a sense of political personhood. Yet, as Guest has noted, trade with Islanders unsettled 
British explorers (especially Cook), who worried that Tahitians cleverly understood "the exploitability of desire" in their encounters. ${ }^{71}$ In an adjacent affective grid, Vanessa Smith has demonstrated the importance of friend relations in $\mathrm{Pa}$ cific commercial discourse, finding in the Tahitian notion of taio, which refers to a set of ritualized bonds and "exogamous alliances," an "Oceanic friendship pact" that "entailed an ongoing exchange of goods and services" between Europeans and Islanders. ${ }^{72}$ These types of bonds, Smith argues, provided opportunities for a "change of identities with a completely foreign other," an exchange that involved "not a swapping of identities but two completely new identities, invented between subjects. ${ }^{173}$ Although taio exchanges were primarily bonding among men, Smith suggests that the poetic impersonations of Purea resulted from attempts to police her unorthodox participation with British explorers in this model of Oceanic friendship. ${ }^{74}$

I would suggest that these poems-even when they satirize Purea-propose another possibility as well: the creation of fictional Tahitians who entice British readers into the types of social relations that Guest and Smith observe were unsettling to an explorer like Cook. These bonds occurred not through the faceto-face exchange of trade or taio, but rather through attachment to synthetic Tahitian speakers like Oberea. These attachments are particularly evident in the subset of poems that imagine a sexual relationship and ensuing correspondence between Oberea and Banks, a wealthy amateur botanist who accompanied Cook's first expedition to the Pacific from 1768 to 1771. Banks was an obvious target, John Gascoigne notes, because he participated avidly in Tahitian social life and because hints of his affairs with Tahitians began as soon as he returned to England. ${ }^{75}$

I focus on these dynamics in two of the earliest and most important of these poems: "An Epistle from Oberea, Queen of Otaheite, to Joseph Banks, Esq." (1774) and what purports to be Banks's reply, "An Epistle from Mr. Banks, Voyager, Monster-hunter, and Amoroso, to Oberea, Queen of Otaheite" (1773). ${ }^{76}$ Both were published anonymously, and their authorship remains uncertain. ${ }^{77}$ J. C. Beaglehole describes them as "repetitive and excessively tedious," particularly with their inaccurate explanations of Banks's sexuality, but Beaglehole misrecognizes the significance of their repetition and inaccuracy. ${ }^{78}$ These poems were modeled on Ovid's Heroides, a series of epistles from women to absent male lovers primarily concerned with portraying women as speakers who transmit their frustrations to a wider community of readers. ${ }^{79}$ The falsified correspondence between Banks and Oberea renovates this Ovidian form of address to incorporate readers into their intimate exchange of sexual knowledge, situating readers somewhere between participants and observers.

These inviting addresses, therefore, were never meant to convince readers of the accuracy or authenticity of these poems. John Scott's title page from the "Epistle from Oberea" absurdly promises that it was translated by "T.Q.Z Esq.," a "Professor of the Otahetie Language in Dublin, and all the Languages 
of the undiscovered Islands in the SOUTH SEA." "An Epistle from Banks" continues this transparent deceit, claiming it was "transfused by A.B.C. Esq.," an "Irish Translator" and "Second Professor of Otaheite, and of every other unknown Tongue." Avowing such fanciful origins demolishes any guise of authenticity. These poems were intended to create textual environments within which readers could experience an erotic encounter with strangers who were made intimate by the poems' form. As Kathleen Lubey notes, the "pleasures of erotic reading derive from some combination of imagining others' libidinal arousals and, perhaps, feeling similar stirrings in one's own body." ${ }^{\prime 80}$ In these instances, the participants are vestigial and the connection is, like the act of impersonation itself, vicarious and imaginary. These appropriations of Tahitians do not seek quasi-anthropological authenticity or a satirical facetiousness, but instead attempt to inculcate a carefully constructed sense of inauthenticity that facilitates erotic arousal. ${ }^{81}$

A crucial scene in "An Epistle from Banks"-which claims to describe his reaction to the public copulation overseen by Oberea-reveals how the inauthentic and the erotic fit together. An engraving of this scene forms the frontispiece of the poem, and it shows a nearly naked Tahitian woman who lifts her clothes to expose her tattooed posterior (to readers) and her genitalia (to onlookers) (see Fig. 2). The fictional Banks narrates this moment:

While, as she turns her painted bum to view,

With fronts unblushing, in the public stew,

They search each crevice with a curious eye

To find exotics-where they never lie.

O shame! were we, great George, thy gallant crew,

And had we-damn it—nothing else to do,

But turn thy great design to filthy farce,

And search for wonders on an Indian's A-? ${ }^{82}$

Together with the frontispiece, this excerpt places readers in the position of Banks and Cook's "gallant crew," who, by inspecting Tahitian bodies, turn exploration of the Pacific into a "filthy farce" and seek "for wonders on an Indian's A[rse]." It describes cross-cultural sexual liaisons and shows nearly naked Tahitians to indulge readers' prurience, while at the same time laughing at these appetites. After describing this "filthy farce," the speaker jokes:

But then to print our tale! O curse the thought!

Curse those who sold,-a blush for those who bought.

Fine tales for misses!-charming table-talk!

Delightful too in each meandering walk,

Through Britain's ample plains!-The lustful squire

With ease may quench his unsubdu'd desire..$^{83}$ 


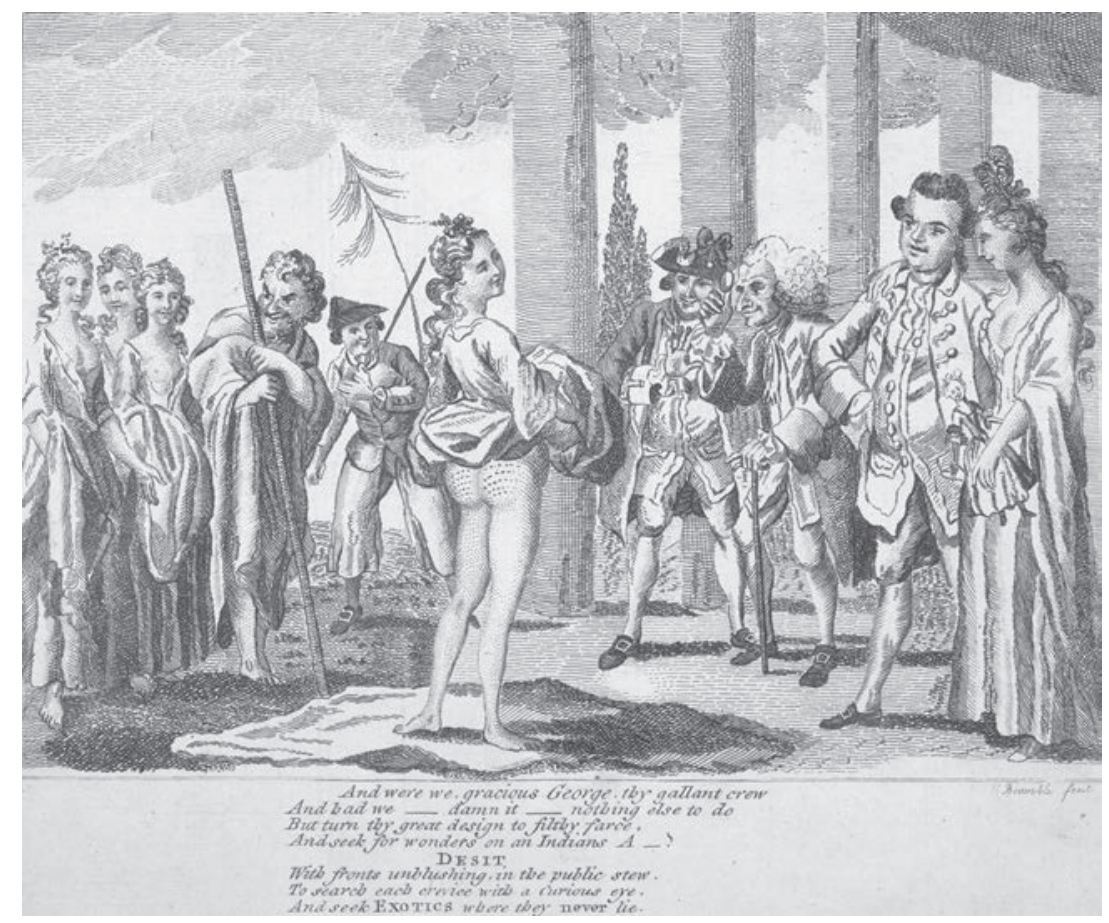

Fig. 2: Frontispiece, "An Epistle from Mr. Banks, Voyager, Monster-hunter, and Amoroso, to Oberea, Queen of Otaheite" (London, 1773). Image courtesy of the Alexander Turnbull Library.

Daniel O'Quinn notes that this poem "restages ... the key scenes of sexual practice from Hawkesworth as spectacles of Banks's pornographic desire," turning the poem into a theatrical critique of how narratives of exploration slip into libertinism. ${ }^{84}$ I think the poem's dynamics of vicarious participation and observation offer a different imperative for consumers of these texts. This poem is disingenuous: while claiming to be concerned with its potential for immorality and onanism (the masturbating squire who may quench his passions "with ease"), the poem indulges unashamedly in that licentiousness, laid bare by the inclusion of an engraving displaying an "Indian's A[rse]."

At other times this licentiousness deranges European and Tahitian bodies, transmuting them into plants and insects in lengthy descriptions of botanical and zoological copulation, for example, when Banks fantasizes that he is a flyeating plant and Oberea a fly that can "buz around, and in my bosom die" or when he longs for her to be the plant so that she can "clasp thy tendrils round my brawny rump." 86 In "An Epistle from Oberea," Oberea likewise wishes she could "vegetate" for Banks, so that "at thy approach I'd all my flowers expand, / And weave my wanton foliage round thy hand." ${ }^{187}$ Bridget Orr claims that 
these instances of sexual traffic portray miscegenation as "aristocratic excess" and as a "perversion of sophistication . . . to limit its threat to sexual norms." ${ }^{88} \mathrm{I}$ think differently-the botanical sexuality represented in these poems absolves readers from feeling any shame about the erotic potential of virtual sexual encounters. They are another example of how botany licensed "variety in social and sexual organization." 89 Tahitians are to be engaged and enjoyed, much as the onlookers in the engraving do. Even as these poems lampoon the impulse to explore exotic bodies, they present their inauthentic speaking subjects, impersonated voices, and simulated bodies as opportunities to imagine alternate sexual arrangements, even while satirizing the mechanisms (like print) that make those arrangements available to readers. At their most experimental, these acts of impersonation distort the boundaries of European and Tahitian bodies, as they intertwine and clasp each other, to produce a tropicalized sex that obscures the boundaries between speaker and object, European and Tahitian, and that concatenates mammalian, botanical, and insect sex.

\section{VENTRILOQUISM AND EXOTICISM AS RELATIVIZED AGENCY: READING THE INAUTHENTIC}

It is my argument that the impersonation of Tahitians in these poems from the 1770s was part of the larger engine by which European and Tahitian sexual regimes were transformed by contact with one another. These impersonations construct temporary subjects constituted by appreciation of English aesthetic norms (white English women in "Omiah's Farewell") or by erotic attachment (to white British explorers in the epistles between Banks and Oberea). These techniques depend upon ventriloquism and exoticism, but that need not necessitate that we perceive impersonation as merely an expression of those brutal objectifications that arise from colonial exploration and the subsequent exploitation of Islanders. Rather, we should acknowledge that the pleasures of reading these temporary subjects depends upon participating in the sexual entanglement between Tahitians and the British, most clearly troped in those instances when the boundaries blur between Tahitian and European bodies and between the vegetal and the human.

Such entanglements, as Rey Chow argues, cause "derangement in the organization of knowledge" through "unprecedented adjacency and comparability or parity," which results in the "relativization of agency." that this relativism is the promise of experiencing the sexual performances of obviously inauthentic literary personae. Beyond the well-known disruptions provoked by representing Tahiti as either a sexual paradise or immoral dystopia, these poems also offer the direct addresses of vicarious subjects who are manufactured to bypass those blockages erected - then as now-by attempts to anchor literary representations in notions of authenticity. These poems confirm and extend our understanding that subjectivity is a performance often involving uncomfortable appropriations. 
Even as scholars understand this, we continue to employ voice and sexuality retroactively as indicators for contests over subjectivity and agency. Therefore, we can examine the sophisticated forms of address in these poems to add to our comprehension of how writing shaped colonial subjectivities and sexualities. Historians and literary critics of the Pacific have assessed the significance of sexuality during early encounters between the British and Polynesians at length. Yet the essential role of impersonation for the cross-racial sexual innovation found in these poems has not been acknowledged, likely because these poems seem gossipy or conventional. As a group, these impersonations demonstrate profound ambivalence about Pacific exploration, so their politics can be difficult to categorize, but they were also addressed to a savvy community of authors and readers who are assumed to be competent enough to assess the jokes, satires, voices, and critiques of their own sexuality. To concentrate on the techniques that link impersonation and subjectivity thus requires understanding not only to the familiar dynamics of cultural appropriation, as it intersects with agency, but also to the erotics of reading Tahitian speakers with unstable sensibilities and imagined sexual desires. The poems of the Omiah and Oberea cycles publicize these difficulties as part of their poetic form by presenting inauthentic subjects in asymmetrical relationships with readers who hunger for depictions of those virtual voices and eroticized bodies.

We can trouble our models of agency and of subject-making by examining how colonized subjects-particularly projected ones-were recruited to excite Europeans about representations of their own desires. The ventriloquized voices and eroticized bodies of these poems usurp actual Tahitians, as scholars like Guest and Jocelyn Hackforth-Jones have noted, but they also make it possible to track the virtual projections associated with these historical beings. ${ }^{91}$ These projections are the unwanted siblings and printed clones that travel with Mai and Purea through the eighteenth-century world. Recuperating these poetic impersonations into our criticism requires that we assess the contours and function of colonial archives and the practices that grasp them, attaching to them the same sophistication that Vanessa Smith uses to investigate the invention of new identities within the friendship bonds of early Oceanic encounters. More specifically, such poetry requires us to think differently about the possibilities of hearing the subaltern voice or seeing the exotic body, or to understand anew the historical contingency of being unable to hear or see them correctly. It also demands rereading these types of poems for the discontinuities between fabricated speakers and actual Tahitians while also realizing how these impersonations necessarily constrain their historical experience and our reading practices: in our criticism, there can be no Mai without Omai and Omiah as companions; there is no Purea without her twin Oberea. From these residuesthat is, with these counterfeit siblings and printed clones, with what Aravamudan calls "stubborn material traces" — we may be able to recreate an obfuscated picture of these historical beings' agency as it is unevenly constituted by sexual- 
ity during the late eighteenth-century representation of Tahiti. ${ }^{92}$ If we confine ourselves to repeating the impossibility of recovering Mai's or Purea's "authentic" voices, or of seeing beyond their status as exoticized objects overwritten by British appropriators, we lose a level of richness that extends our study of the colonized and their agency. Sexual knowledge is particularly difficult to come by - the ways that it is silenced, censored, and erased are myriad-so that impersonation may provide a damaged yet still valuable source of information that we should not be afraid to use.

More knowledge is gained from these impersonations about the sophisticated, ironic ways that British authors saw their own literature's capacity expanded by its connection with exotic voices and bodies than is gained about actual Tahitians themselves. And yet these poems persistently indulge-with a knowing shrug-in the spectacle of rewriting the exotic body, a process that reveals that the complexity of sexualized speakers and temporary subjects was reenergized in Britain by its authors' appropriations of Polynesians abroad. While we can see the limited possibilities from which these impersonations originate, we should also see and hear how the projections of Tahitian virtual subjects enable and limit our own reading practices even now.

\section{NOTES}

1. Mai was originally from Raiatea, an island near Tahiti, and a member of raatira, a second order of society. He arrived in Tahiti as a young refugee fleeing from invading Boraborans. See E. H. McCormick, Omai: Pacific Envoy (Auckland, 1977), 1-3 and 117-18. Harriet Guest reasons that Mai believed Britain might ally with him and help him kill his enemies (Empire, Barbarism, and Civilization: Captain Cook, William Hodges, and the Return to the Pacific [Cambridge, 2007], 152).

2. See P. J. Marshall and Glyndwr Williams, The Great Map of Mankind: Perceptions of New Worlds in the Age of Enlightenment (Cambridge, Mass., 1982), 60.

3. Srinivas Aravamudan, Tropicopolitans: Colonialism and Agency, 1688-1804 (Durham, 1999), 17-19. Use of the terms "virtualization" and "virtuality" differs from the sense with which they are used in digital media and humanities, but, as Aravamudan notes, our renewed understanding of the print's virtualizations is indebted to the examination of digital texts (17).

4. Aravamudan, 17.

5. The terminology of subject and subjectivity has a complicated history. For an excellent overview, see Sherry B. Ortner, "Subjectivity and Cultural Critique," Anthropological Theory 5, no. 1 (2005): 31-52, 31-34. I use the term "subject" to access its sense of agency, action, and participation in representation through tropes of speech. I use it in distinction from other terms such as "subjecthood," with its connotation of English political and legal history; for more on that tradition, see Paul D. Halliday, Habeas Corpus: From England to Empire (Cambridge, Mass., 2010), 177-212. And I use "subject" rather than "person," which, as Monique Allewaert notes, is "an entity on the verge of entering a political community" (Ariel's Ecology: Plantations, Personhood, and Colonialism in the American Tropics [Minneapolis, 2013], 10).

6. Pamela Cheek, Sexual Antipodes: Enlightenment Globalization and the Placing of Sex (Stanford, 2003), 2.

7. Cheek, 4. 
8. See Jonathan Lamb, Preserving the Self in the South Seas, 1680-1840 (Chicago, 2001), esp. 3-49, 114-16, and 124-25.

9. For more on autonomy and privacy in sexual relationships, see Lawrence Stone, The Family, Sex, and Marriage in England, 1500-1800 (New York, 1979). See Tim Hitchcock, English Sexualities, 1700-1800 (New York, 1997) on the association of sex with companionate marriage and procreation, and Anthony Fletcher's Gender, Sex, and Subordination in England, 1500-1800 (New Haven, 1995) for more on the effect of these changes on women.

10. See E. A. Wrigley's "The Growth of Population in Eighteenth-Century England: A Conundrum Resolved" (Past and Present 98 [February 1983]: 121-50); and Wrigley and R. S. Schofield, The Population History of England, 1541-1871: A Reconstruction (Cambridge, Mass., 1981). On sexual penetration and economy, see Henry Abelove, Deep Gossip (Minneapolis, 2005), 27-28; and Thomas Laqueur, Making Sex: Body and Gender from the Greeks to Freud (Cambridge, Mass., 1990), esp. 149-54. For more on the emergence of homosexuality, see Randolph Trumbach, Sex and the Gender Revolution, Volume One: Heterosexuality and the Third Gender in Enlightenment London (Chicago, 1998), 6-12.

11. G. S. Rousseau and Roy Porter, introduction to Sexual Underworlds of the Enlightenment, ed. Rousseau and Porter (Chapel Hill, 1986), 1-25, 2.

12. Hitchcock, "The Reformulation of Sexual Knowledge in Eighteenth-Century England," Signs: Journal of Women in Culture and Society 37, no. 4 (Summer 2012): 823-31, 824.

13. Lee Wallace, Sexual Encounters: Pacific Texts, Modern Sexualities (Ithaca, 2003), 2.

14. See esp. Nicholas Thomas, Entangled Objects: Exchange, Material Culture, and Colonialism in the Pacific (Cambridge, Mass., 1991), 186, 5; and Thomas, Islanders: The Pacific in the Age of Empires (New Haven, 2012), 55.

15. See Cheek, 142. See also John Hawkesworth, An Account of the Voyages Undertaken by the Order of His Present Majesty ... , 2nd. ed., 3 vols. (London, 1773).

16. [John O'Keefe and] William Shields, A Short Account of the New Pantomime Called Omai, or, A Trip Round the World ... (London, 1785). Doris. L. Garraway claims that Denis Diderot "liberally invokes the speaking native" in a futile attempt to produce a "counter discourse to colonialism" ("Of Speaking Natives and Hybrid Philosophers: Lahontan, Diderot, and the French Enlightenment Critique of Colonialism," in The Postcolonial Enlightenment: Eighteenth-Century Colonialism and Postcolonial Theory, ed. Daniel Carey and Lynn Festa [Oxford, 2009], 207-39).

17. See Lamb; Neil Chambers, Joseph Banks and the British Museum: World of Collecting, 1770-1830 (London, 2007); Nigel Leask, Curiosity and the Aesthetics of Travel Writing, 1770-1840: 'From an Antique Land' (Oxford, 2002). Kathleen Wilson describes attempts to reconcile Polynesian sexual practices with British norms in The Island Race: Englishness, Empire, and Gender in the Eighteenth Century (New York, 2003), 169-200. However, the poems I describe do not share the sense that Cook's voyages were, as Wilson puts it, about "reconstituting the imperial project as an essentially scientific and philanthropic enterprise, designed to benefit all mankind" (171).

18. On the kinship between vicariousness and sentimental reading, see Paul Kelleher, "If Love Were All: Reading Sedgwick Sentimentally," in Regarding Sedgwick: Essays in Queer Culture and Critical Theory, ed. Stephen L. Barber and David M. Cook (New York, 2002), 143-61, 150-51.

19. For a description of this action, see Kathleen Lubey, Excitable Imaginations: Eroticism and Reading in Britain, 1660-1760 (Lewisburg, 2012), 5-8.

20. Increases in pornographic publication in eighteenth-century Europe, Lynn Hunt notes, were motivated by its potential to combine titillation with social critique (The Invention of Pornography: Obscenity and the Origins of Modernity, 1500-1800 [New York, 1993], esp. 33-45).

21. Here I recast Thomas Kuhn's notion of "normal science" as "puzzle-solving" from The Structure of Scientific Revolutions, 3rd ed. (Chicago, 1996), 35-42. 
22. Anne Salmond, Aphrodite's Island: The European Discovery of Tahiti (Berkeley, 2010), 115 .

23. James Cook, A Voyage Round the World, Performed in His Britannic Majesty's Ships the Resolution and Adventure, in the Years 1772, 1773, 1774, and 1775 (Dublin, 1777), 166.

24. See Salmond, 119.

25. Louis du Bachaumont, quoted in Salmond, 120.

26. McCormick, 96; "Genuine Account of Omiah, a Native of Otaheite," Annual Register (London, 1774), 61.

27. Porter, "The Exotic as Erotic: Captain Cook at Tahiti," in Exoticism in the Enlightenment, ed. Rousseau and Porter (Manchester, 1990), 117-44, 118-21. For more on reactions to Mai as a sexual being, see McCormick, 111-34.

28. For more on these Edenic codes, see Vladimir Kapor, "Shifting Edenic Codes: On Two Versions of the Golden Age in the Late Eighteenth Century," Eighteenth-Century Studies 21, no. 3 (2008): 217-30, 218.

29. See Salmond, 391. For more on the significance of bark cloth, see The Cambridge History of the Pacific Islands, ed. Donald Denoon et al. (Cambridge, 1997), 108.

30. Salmond, 393. On the friendship between Joseph Banks and Mai, see also Vanessa Smith, "Banks, Tupaia, and Mai: Cross-Cultural Exchanges and Friendship in the Pacific," Parergon 26, no. 2 (2009): 139-60, esp. 154-59.

31. "Genuine Account," 61.

32. Salmond, 397.

33. Paul Goring, The Rhetoric of Sensibility in Eighteenth-Century Culture (Cambridge, 2005), 19.

34. Guest, Empire, 70, 72.

35. Guest focuses primarily on William Hodges's drawings of tattooed Maori, whose bodies were both "signs of the exotic" and "signs of sentiment," establishing opportunities for "sympathetic recognition" (Empire, 88), unlike Joshua Reynolds's portrait of Mai.

36. McCormick, 183-87. McCormick's account is immensely detailed and hugely informative. His readings of these Tahitian impersonations, however, are ultimately descriptive of the poems and their historical context.

37. "Omiah's Farewell; Inscribed to the Ladies of London" (London, 1776), 10, 7, 3. Seeing British women as more beautiful than Tahitian women differs from the French tradition, in which Tahitians quite favorably compared to Europeans; see Andy Martin, "The Enlightenment in Paradise," Eighteenth-Century Studies 41, no. 2 (Winter 2008): 203-16, 205.

38. "Omiah's Farewell," 2.

39. "Numidian" typically refers to northern Africa. Kate Fullagar argues that Mai was recognized as the latest iteration of colonialism's examination of difference ("Reynolds's New Masterpiece: From Experiment in Savagery to Icon of the Eighteenth Century," Culture and Social History 7, no. 2 [2010]: 191-212, 196).

40. “Omiah's Farewell," 2. On the significance of cosmetics, see Tita Chico, Designing Women: The Dressing Room in Eighteenth-Century Literature and Culture (Lewisburg, 2005), 109-17.

41. Roxann Wheeler, The Complexion of Race: Categories of Difference in EighteenthCentury British Culture (Philadelphia, 2000), 269.

42. Wheeler, 269.

43. Wallace notes that Pacific discovery was "often associated with unauthorized sexual arrangement and gender crossing" (10).

44. "Omiah's Farewell," 3.

45. “Omiah's Farewell," 10, 8.

46. For Guest, this reconfirms Mai as an "ornamental or frivolous utility" (Empire, 154). On sentiment and masculinity, see G. J. Barker-Benfield, The Culture of Sensibility: Sex and Society in Eighteenth-Century Britain (Chicago, 1992), esp. 85-103, 141-48, and 247-50. 
47. David M. Halperin, How to Do the History of Homosexuality (Chicago, 2002), 111.

48. Peter Hulme, Colonial Encounters: Europe and the Native Caribbean, 1492-1797 (New York, 1986), 229.

49. “Omiah's Farewell," 5.

50. On the imbrication of attraction and fear of the foreign, see Rajani Sudan, Fair Exotics: Xenophobic Subjects in English Literature, 1720-1850 (Philadelphia, 2002), esp. 7-8. However, in these Pacific impersonations, we do not see the "complications of foreign identity and agency were... reduced to the material body" (8).

51. Bernard Smith, European Vision and the South Pacific, 2nd ed. (New Haven, 1985), 83. I see greater similarity between impersonations of Mai and Purea than does Smith, who claims that poems appropriating her present a "mock-heroic melancholy" that perceives Tahiti as a "tainted paradise" (48-49).

52. "An Historic Epistle from Omiah, to the Queen of Otaheite; Being his Remarks on the English Nation" (London, 1775), line 38.

53. "An Historic Epistle," lines 131-34.

54. "An Historic Epistle," lines 40, 45-46.

55. "An Historic Epistle," lines 537, 539.

56. "An Historic Epistle," lines 566-68.

57. "An Historic Epistle," lines 553-54.

58. "An Historic Epistle," lines 738, 744.

59. "An Historic Epistle," line 746.

60. See Bernard Smith, 49.

61. Patty O'Brien, The Pacific Muse: Exotic Femininity and the Colonial Pacific (Seattle, 2006), 61-67. See also Hawkesworth, Account, 2nd ed., 2:128.

62. See Laura Rosenthal, Infamous Commerce: Prostitution in Eighteenth-Century British Literature and Culture (Ithaca, 2006), 197.

63. For more, see Thomas, Islanders, 15, 88; Salmond, 64; and Cambridge History of the Pacific, 130-31. For an account of Hawkesworth's importance, see Cheek, 142-47.

64. Cheek, 145-46.

65. Courtenay, "An Epistle (Moral and Philosophical) from an Officer at Otaheite to Lady Gr*s**n*r [Grosvenor]" (London, 1774), 6.

66. Courtenay, 6.

67. Courtenay, 6 .

68. Bridget Orr makes a similar point about this poem in "'Southern passions mix with northern art': Miscegenation and the Endeavour Voyage" (Eighteenth-Century Life 18, no. 3 [November 1994]: 212-31, 228).

69. Courtenay, 20-21.

70. For more on this debate, see Philip Stern, The Company-State: Corporate Sovereignty and the Early Modern Foundations of the British Empire in India (Oxford, 2011), and Nicholas Dirks, The Scandal of Empire: India and the Formation of Imperial Britain (Cambridge, Mass., 2008).

71. Guest, Empire, 109.

72. Vanessa Smith, Intimate Strangers: Friendship, Exchange, and Pacific Encounters (Cambridge, 2010), 69.

73. Vanessa Smith, Intimate Strangers, 102.

74. Vanessa Smith, Intimate Strangers, 94-95.

75. John Gascoigne, Joseph Banks and the Enlightenment: Useful Knowledge and Polite Culture (Cambridge, 1994), 50-51. Gascoigne suggests that Banks may have acknowledged having sex with Islanders in his private papers. He also notes that these poems compared reports of Banks's salacious escapades overseas with those his libertine companions in England, though "Banks's escapades were ... by no means unusual in his class" (51).

76. For a history of these poems and the rumors that provoked them, see The Endeavour Journal of Joseph Banks, 1768-1771, 2 vols., ed. J. C. Beaglehole (Sydney, 1962), 1:100- 
102; and McCormick, 88-93. The title pages of these poems carry later publications dates, even though the date lines of the introduction claim to be from 1773. The other poems that engaged in this epistolary exchange involving Oberea and Banks included a scornful second reply from Oberea, also composed by John Scott, and an anonymous missive supposedly from Harriett Blosset, alleged to be secretly Banks's fiancée.

77. They have been attributed to John Scott, later John Scott-Waring, an East India Company employee and London agent for Warren Hastings. For more, see The Oxford Dictionary of National Biography, s.v. "Scott-Waring, John." Beaglehole (see "Introduction: The Young Banks," in Endeavour Journal, 1:101) and Bernard Smith (49) argue that "An Epistle from Banks" was written by Scott. Colin Roderick disagrees ("Sir Joseph Banks, Queen Oberea, and the Satirists," in Captain James Cook: Image and Impact, ed. Walter Veit [Melbourne, 1972], 67-89, 77).

78. Beaglehole, "Introduction: The Young Banks," 102.

79. See Laurel Fulkerson, The Ovidian Heroine as Author: Reading Writing, and Community in the Heroides (Cambridge, 2005), esp. 1-22, 55-66.

80. Lubey, 13.

81. For more on the importance of inauthenticity in impersonation, see James Mulholland, Sounding Imperial: Poetic Voice and the Politics of Empire, 1730-1820 (Baltimore, 2013), 156-66.

82. “An Epistle from Mr. Banks, Voyager, Monster-hunter, and Amoroso, to Oberea, Queen of Otaheite" (London, 1773), 13.

83. "An Epistle from Banks," 13.

84. Daniel O'Quinn, Staging Governance: Theatrical Imperialism in London, 1770-1800 (Baltimore, 2005), 78-79.

85. For an extensive account of anxieties over masturbation, see Laqueur, Solitary Sex: A Cultural History of Masturbation (New York, 2003), esp. 235-45.

86. "An Epistle from Banks," 14.

87. "An Epistle from Oberea," 12. Exoticism was associated with rare plants before it conveyed a modern sense of cultural difference; see Christa Knellwolf, "The Exotic Frontier of the Imperial Imagination" (Eighteenth-Century Life 26, no. 3 [Fall 2002]: 10-30, 14-15). There was a tradition of seeing foreign landscapes as sexual opportunity; see Julie Peakman, Mighty Lewd Books: The Development of Pornography in Eighteenth-Century England (New York, 2003), 96-103. For more on the dangers of derangement incumbent on the subject in the tropics, see Allewaert, 10-17.

88. Orr, 223.

89. Greta LaFleur, "Precipitous Sensations: Herman Mann's The Female Review (1797), Botanical Sexuality, and the Challenge of Queer Historiography," Early American Literature 48, no. 1 (2013): 93-123, 105. Matthew Goldie argues that this is part of a larger "debate about a natural versus a social basis for sexuality" (The Idea of the Antipodes: Place, People, and Voices [New York, 2010], 104-6).

90. Rey Chow, Entanglements, or Transmedial Thinking about Capture (Durham, 2012), 10-11, 179-81.

91. Guest claims that "where Mai is offered a voice his comments are close to those of observers writing about him" ("Ornament and Use: Mai and Cook in London," in A New Imperial History: Culture, Identity, and Modernity in Britain and the Empire, 1660-1840, ed. Kathleen Wilson [Cambridge, 2004], 317-44, 324). Jocelyn Hackforth-Jones asks rhetorically, "How do we read these [texts] and how do we 'insert' and include Mai's voice as we read them?," suggesting that we cannot ("Mai/Omai in London and the South Pacific: Performativity, Cultural Entanglement, and Indigenous Appropriation," in Material Identities, ed. Joanna Sofaer [Malden, 2007], 13-30, 16).

92. This is also partly an answer to Chow's query about "how we can write about the native by not ignoring the defiled, degraded image that is an inerasable part of her status" (Writing Diaspora: Tactics of Intervention in Contemporary Cultural Studies [Bloomington, 1993], 30). 